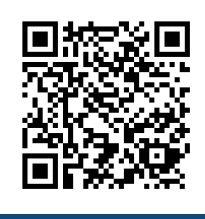

Keywords:

Ammonia

Defoliation

Chemical pruning

Herbicide

Glutamate

Historic:

Received 06/03/2018

Accepted 23/08/2018

Correspondence:

fhkrenchinski@gmail.com

Fábio Henrique Krenchinski ${ }^{\mathrm{la}+}$, Renato Nunes Costa ${ }^{\mathrm{lb}}$, Natalia da Cunha Bevilaqualc, João Alexandre Galon ${ }^{2 a}$, Johnny Angelo de Oliveira ${ }^{2 b}$, Caio Antonio Carbonari ${ }^{1 d}$ Edivaldo Domingues Velinile

\title{
EARLY PRUNING OF EUCALYPTUS PLANTS USING GLUFOSINATE AMMONIUM
}

KRENCHINSKI, F. H.; COSTA, R. N.; BEVILAQUA, N. C.; GALON, J. A.; OLIVEIRA, J. A.; CARBONARI, C. A.; VELINI, E. D. Early pruning of eucalyptus plants using glufosinate ammonium. CERNE, v. 24, n. 3, p. I62-I68, 2018.

\section{HIGHLIGHTS}

Small changes in glufosinate, glutamate and ammonia levels were found, in eucalyptus plants.

The treated eucalyptus plants had defoliation above $80 \%$ and $90 \%$ pruning with glufosinate application.

Pruning using glufosinate ammonium not reduced growth in eucalyptus plants.

Glufosinate can be used for chemical artificial pruning of eucalyptus plants since it does not affect their physiology and growth.

\section{ABSTRACT}

Eucalyptus stands out in the Brazilian silvicultural sector as the most planted tree species for commercial purposes thus, practices that facilitate management and improve wood quality are increasingly required. Although artificial mechanical pruning has been used for this crop, the use of herbicides for pruning can be more practical, rapid and have lower costs. Thus, the objective of this work was to evaluate the use of glufosinate ammonium in the chemical pruning of eucalyptus plants. Eucalyptus seedlings were transplanted into I0-L pots filled with soil and substrate and subjected to the treatments (mechanical pruning, chemical pruning, and no pruning) 90 days after transplanting. Lateral branches were cut with pruning shears for the mechanical pruning. Glufosinate ammonium (500 g $\left.\mathrm{a} \cdot \mathrm{i} \cdot \mathrm{ha}^{-1}\right)$ was applied to the sides of the plants for the chemical pruning, simulating a fieldplanting row $(3.5 \times 2.0$ meters $)$, using a $\mathrm{CO}_{2}$-pressurized sprayer; the untreated branches were covered with plastic bags to avoid receiving the herbicide. The percentage of artificial pruning used was $60 \%$ of the vertical height of the eucalyptus plants. Glufosinate, glutamate, and ammonia contents, electron transport rate, percentage of pruning, plant height, number of leaves, and dry matter mass of the plants were evaluated. The application of glufosinate ammonium defoliate the treated branches and did not affect significantly the parts of the plants that did not receive the herbicide regarding the evaluated compounds, and growth of the plants, denoting that glufosinate ammonium can be used for chemical pruning of eucalyptus plants.

I São Paulo State University, Botucatu, São Paulo, Brazil, ORCID: 0000-000 I-7| | 6-9944a , 0000-000 I-8756-0569 , 0000-0003-3134-7608c, 0000-0002-0383-2529 , 0000-0003-0431-5942

${ }^{2}$ Bayer Environmental Science, Brazil - ORCID: 0000-000I-8836-2695a, 0000-000 I-623 I-5372 


\section{INTRODUCTION}

The silvicultural sector in Brazil is responsible for $91 \%$ of the wood produced in the national territory, with an area of 10 million hectares in 2016; eucalyptus plantations cover 7.5 million hectares of this area, representing $75 \%$ of the total planted trees (IBGE, 20I6). According to Cezana et al. (20I2), timber companies have sought logs of high quality and yield, which is achieved through investment in adequate management. Artificial pruning is one of the practices that assists in the production of high-quality, defect-free timber, by increasing its strength, durability, and beauty in eucalyptus plantations (Vale et al., 2002; Finger et al., 2001 ; Pires et al., 2002; Hoppe and Freddo, 2003; Polli et al., 2006). The efficiency of artificial pruning is dependent on the age of the plants, the clonal material, as well as area to area, some authors have reported artificial pruning from 20 to $70 \%$, depending on the size of the plants and spacing between plants used (Ferraz Filho et al., 20l6a; Ferraz Filho et al., 20l6b; Cezana et al., 2012). When performed early, artificial pruning can also assist in weed management, since herbicides can be used without damaging the shoots (Machado et al., 20l4).

Pruning is the withdrawal or fall of branches or leaves from the trunk of trees. It happens naturally due to biotic agents in the medium, or artificially by humans. Mechanical removal of branches from part of a tree trunk is a type of artificial pruning (Cezana et al., 2012; Polli et al., 2006; Vale et al., 2002). This practice presents good results when the plant's phenological and sanitary characteristics and the procedure's method and management is considered, allowing the evaluation of the recover capacity of the plant (leaf area) after pruning (Pires et al., 2002; Pulrolnik et al., 2005).

Artificial mechanical pruning is commonly used in eucalyptus plantations, however, the use of herbicides for artificial chemical pruning is an alternative to remove undesirable tree branches. The use of herbicides for pruning can be used. However, an herbicide of rapid action, and low or no translocation to other parts of the plant must be chosen to avoid damaging the plant's growth and physiology.

Glufosinate ammonium is an herbicide with these characteristics. This herbicide inhibits the action of the glutamine synthetase enzyme, which catalyzes the formation of glutamine through glutamate and ammonia (Logusch et al., 1991). This herbicide presents high absorption and low translocation (Coetzer et al., 200I; Everman et al., 2009). It is analogous to glutamate in the binding to glutamine synthetase enzymes; the inhibition of this enzyme reduced glutamine levels and causes rapid and intense accumulation of ammonia in the plant (Dayan et al., 2015). Currently, no study describing the use of glufosinate ammonium or other herbicides for artificial chemical pruning in eucalyptus plants is found.

Considering the importance of artificial pruning for the quality of eucalyptus logs, and the use of herbicides for this purpose, the objective of the present work was to study the behavior of glufosinate ammonium in the artificial chemical pruning, and the physiological aspects and subsequent development of eucalyptus plants.

\section{MATERIAL AND METHODS}

The experiment was carried out in Botucatu, state of São Paulo, Brazil, in a greenhouse of the Advanced Weed Research Center of the College of Agronomic Sciences of the Júlio de Mesquita Filho São Paulo State University.

Seedlings of the hybrid Eucalyptus urograndis (clone I- I44) were selected for the experiment. They had 5 to 6 pairs of leaves, height of 30 to $40 \mathrm{~cm}$, and perfect sanity and uniformity. The seedlings were transplanted into I0-L plastic pots filled with a mix of soil and substrate at ratio of $3: 1$. The soil used was from the $0-20 \mathrm{~cm}$ layer of an agricultural area and presented the following chemical characteristics: $\mathrm{pH}\left(\mathrm{CaCl}_{2}\right)$ of $5.3,8.33 \mathrm{mg} \cdot \mathrm{dm}^{-3}$ of $\mathrm{P}$ (resin), I. $33 \mathrm{mmol} \cdot \mathrm{dm}^{-3}$ of $\mathrm{K}, 9.42 \mathrm{mmol} \cdot \mathrm{dm}^{-3}$ of $\mathrm{Ca}$, and $5.14 \mathrm{mmol} \mathrm{dm}^{-3}$ of $\mathrm{Mg}$. The substrate used in the mixture (Carolina ${ }^{\circledR}$; Carolina Soil do Brasil, Santa Cruz do Sul, Brazil) was composed of sphagnum peat, vermiculite, and carbonized rice husks, and had $\mathrm{pH}$ of $5.7 \pm 0.5$.

Soil fertilization consisted of application of the formulation 16-16-16 (NPK) at a rate equivalent to 250 $\mathrm{kg} \mathrm{ha}^{-1} 30$ and 60 days after transplanting. The treatments were applied 90 days after transplanting the eucalyptus, when the plants were well developed, presenting average height of $0.75 \mathrm{~m}$.

A randomized complete block design with five replications was used. The treatments consisted of control without artificial pruning, artificial chemical pruning, and artificial mechanical pruning.

Lateral branches were cut with pruning shears for the mechanical pruning. Glufosinate ammonium (500 g a.i. ha $^{-1}$ ) was applied to the sides of the plants for the chemical pruning, using the Finale ${ }^{\circledR}$ (Bayer, Leverkusen, Germany) herbicide. The upper branches of the plants were protected with plastic bags and, after application, the plastic bags were cut at the top end and remained in the plant for another 2 days to avoid contact with the herbicide, with the objective of evaluating the possible 
translocation of the herbicide to unapplied parts of the plants. The percentage of artificial pruning used was $60 \%$ of the total vertical height of the eucalyptus plants.

Glufosinate ammonium was applied using a $\mathrm{CO}_{2}$-pressurized sprayer with a XRII0.02 (Teejet ${ }^{\circledR}$, Wheaton, USA) nozzle at constant pressure of $200 \mathrm{kPa}$, flow rate of $0.65 \mathrm{~L} \cdot \mathrm{min}^{-1}$, and application speed of $\mathrm{I} \mathrm{ms}^{-1}$, representing a volume of $200 \mathrm{~L} \cdot \mathrm{ha}^{-1}$. The herbicide was applied on both sides of the plants, simulating a field planting row.

\section{Extraction and Determination of Glufosinate and Glutamate}

Four leaves of each treatment were collected at 2, 4, and I 5 days after application (DAA) to quantify their glufosinate and glutamate contents. Leaves were macerated with liquid nitrogen using a mortar and pestle to extract glufosinate and glutamate. An aliquot of 200 $\mathrm{mg}$ of each macerated sample was weighed, packed into I0-mL Falcon tubes, and $10-\mathrm{mL}$ of the extractive solution ( $80 \%$ water and $20 \%$ methanol) (Carbonari et al., 20l6) was added. The samples were taken to an ultrasonic bath for 30 minutes. After centrifugation at 4,000 g for 5 minutes, the supernatant of the samples was filtered in a $0.2-\mu \mathrm{m}$ Millipore filter, and transferred to vials for subsequent LC-MS/MS analysis.

The compounds were quantified in a LC-MS/ MS system, composed of a high-performance liquid chromatography (HPLC) (Prominence UFLC; Shimadzu, Kyoto, Japan) with two LC-20AD pumps, a SIL-20AC autoinjector, a DGU-20A5 degasser, a CBM-20A controller system (fully automated operation), and a CTO-20AC oven (column temperature control). The HPLC was coupled to a hybrid triple quadrupole 3200 Q TRAP mass spectrometer (Applied Biosystems, Foster City, USA). A Synergi $2.5 \mu$ Fusion RP $100 \AA$ chromatographic column $5 \mathrm{mM}$ ammonium acetate in water (Phase A), and $5 \mathrm{mM}$ ammonium acetate in $75 \%$ methanol (Phase B) was used as mobile phases, with a flow of $0.5 \mathrm{ml} \mathrm{min}{ }^{-1}$. The gradient used was: 0 minutes, $50 \%$ Phase B; I minute, 95\% Phase B; 6 minutes 50\% Phase $B$. The total time was 8 minutes, and the time for the compound retaining in the chromatographic column was I.29 minutes; electrospray positive ionization mode was used.

\section{Ammonia Extraction and Quantification}

Four leaves of each treatment were collected at 2, 4, and I5 DAA for ammonia quantification. The ammonia was extracted from fresh tissues, just after the leaf collection. The samples were placed in 50-mL Falcon tubes, adding $40 \mathrm{~mL}$ of water with hydrochloric acid $(\mathrm{pH}$ 3.5) to them, and subjected to an ultrasonic bath for 30 minutes. The ammonia in the solution was quantified by spectrophotometry according to Dayan et al. (20I5), and Wendler et al. (1990), using a spectrophotometer (Cintra 40; GBC Scientific Equipment, Braeside, Australia).

\section{Electron Transport Rate}

Electron transport rate was evaluated with a portable fluorometer (Multi-Mode Chlorophyll Fluorometer OS 5p; Opti Sciences, Hudson, USA), with five readings (replications) per treated plant. The electron transport rate (ETR) in the photosystem II (PSII) was evaluated at 2, 4, 6, 8, and 10 hours, and at $\mathrm{I}, \mathrm{I} .5,2,3,4,5,6,7,8,9,10, \mathrm{II}$, and 12 days after application, in five leaves of each plant. The control plants were evaluated using five leaves of the middle third of the plants. The plants with chemical artificial pruning were evaluated using five leaves of the middle third of the plants and five leaves of the upper third of the plants (protected part).

The percentage of the ETR was calculated considering the results of the chemically treated and untreated plants as a function of the results of the control $(E T R \%=E T R$ of the chemically treated or untreated plants * 100 / ETR control plant).

Percentage of pruning, plant height, number of leaves, and dry matter mass of leaves and branches

Pruning was evaluated at 28 DAA, using a $0-100 \%$ scale, wherein 0 represented plants without pruning, $100 \%$ represented fully debranched and defoliated plants, considering only the part that receive glufosinate ammonium in the artificial chemical pruning. For the debranched, was considered the branches that were dead by the application of glufosinate. Plants subjected to mechanical artificial pruning received maximum scores (100\%) due to the initial removal of branches.

The height of plants (soil surface to apex) was measured at 28 DAA. The leaves of the six branches (to homogenize the pruning treatments) of plants with chemical pruning, mechanical pruning, and control were counted. The leaves were then detached from the branches, both were packed in labeled paper bags and taken to a forced air circulation oven at $60^{\circ} \mathrm{C}$ until constant weight; both parts were weighed to quantify the dry matter mass of the leaves and branches. 


\section{Data analysis}

The data were analyzed for normality by the Shapiro-Wilk test, and subjected to analysis of variance $(p \leq 0.05)$. Significant means were subjected to the mean t-test (LSD; Least Significant Difference) at 5\% probability. The confidence interval was calculated for all parameters evaluated, following the equation I, where in $\mathrm{Cl}$ is the confidence interval, $\mathrm{t}$ is the tabulated $\mathrm{t}$ value at $5 \%$ probability, SD is the standard deviation, and $\sqrt{n}$ is the square root of the number of replications.

$$
\mathrm{CI}=(\mathrm{t} \cdot \mathrm{SD}) \cdot(\sqrt{\mathrm{n}})^{-1}
$$

\section{RESULTS AND DISCUSSION}

Small contents of glufosinate were found in the untreated or protected leaves of eucalyptus plants, denoting a small translocation of the glufosinate. The maximum glufosinate content found was $0.12 \mathrm{mg}$ at 2 DAA in plants subjected to chemical pruning. The glufosinate molecule does not occurs naturally in the plant, thus, no glufosinate were found in plants without pruning or in plants with artificial mechanical pruning (Figure IA). Low translocation of glufosinate to untreated parts of the plant has been reported in several plant species, such as Zea mays, Eleusine indica, Digitaria sanguinalis, Senna obtusifolia (Everman et al., 2009a), Gossypium hirsutum, Amaranthus palmeri, Ipomoea lacunosa (Everman et al., 2009b), Chenopodium album, and Setaria faberi (Maschhoff et al., 2000). This low translocation is an important characteristic for eucalyptus plants that makes feasible the artificial chemical pruning, ensuring that untreated leaves and branches will remain without the effects of the herbicide.

Small differences in glutamate contents were found in plants with artificial chemical pruning at 2 and 4 DAA compared to the control without pruning and the artificial mechanical pruning, with no significance between their means. Glutamate contents were similar between treatments at I5 DAA (Figure IB). Ammonium glufosinate is analogous to glutamate in the binding to glutamine synthetase enzymes, thus, plants treated with this herbicide tend to accumulate glutamate and reduce glutamine amino acid contents (Carbonari et al., 2016; Freitas et al., 2016).

Ammonia content in untreated leaves (protected) was not affected by herbicide application; the treatments were similar within each evaluation period (Figure 2). The maximum accumulation of ammonia found in the leaves was $1.7 \mathrm{mg} \cdot \mathrm{kg}^{-1}$ of fresh mass, normal for these plants (Brito et al., 2017a,b; Brito et al., 2016; Tsai et al., 2006). The accumulation of ammonia can be used as biochemical marker for glutamine synthetase inhibition (Pornprom et al., 2003) and indicator of the herbicide action (Petersen and Hurle, 200I); this denotes that protected parts of eucalyptus plants are not affected by the herbicide.

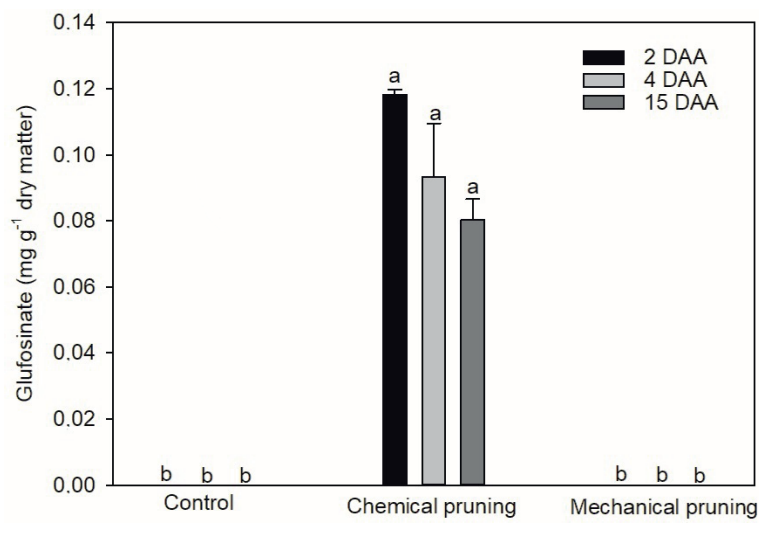

a.

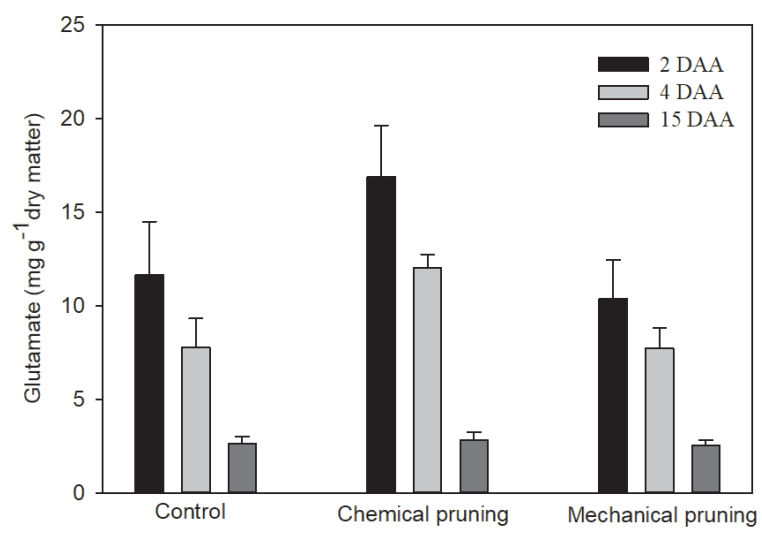

b.

FIGURE I Glufosinate (A) and glutamate (B) contents ( $\mathrm{mg} \mathrm{g}^{-1}$ dry matter) at 2, 4, and 15 days after application (DAA) of treatments in eucalyptus plants (control with no pruning, chemical pruning with glufosinate ammonium, and mechanical pruning). A - Equal lowercase letters in the columns, within each evaluation date, do not differ by the T test (LSD) $(p \leq 0.05)$; B - Not significant by the t-test $(L S D)(p \leq 0.05)$. Vertical bars represent one confidence interval.

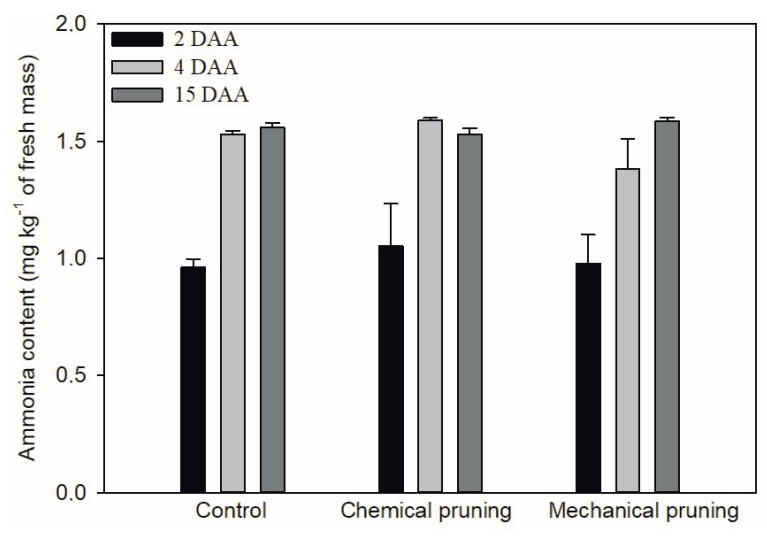

FIGURE 2 Ammonia content (mg.kg-1 of fresh mass) at 2, 4, and 15 days after application (DAA) of treatments in eucalyptus plants (control with no pruning, chemical pruning with glufosinate ammonium, and mechanical pruning). Not significant by the t-test (LSD) $(p \leq 0.05)$. Vertical bars represent one confidence interval. 
The electron transport rate (ETR) of protected leaves of plants treated with artificial chemical pruning, and in leaves of plants treated with artificial mechanical pruning were similar to the ETR found in control plants without pruning (100\%). However, the ETR of treated leaves was negatively affected using glufosinate ammonium (Figure 3). Reduction of ETR in treated leaves is a effect of the application of glufosinate ammonium due to glutamine synthetase inhibition, ammonia accumulation, chloroplast disruption, and protein synthesis inhibition (especially $\mathrm{Qb}$ ), which is directly connected to electron transport in the PSII (Tan et al., 2006; Dayan and Zaccaro, 20I2; Kleczkowski, 1993), resulting in the death of leaves and branches.

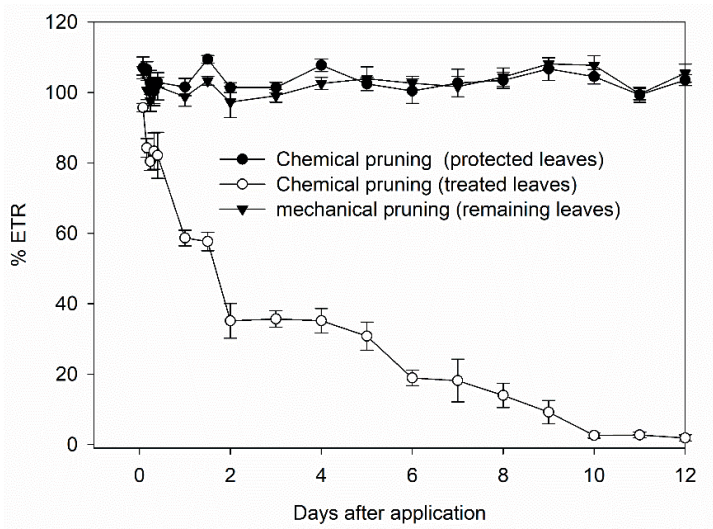

FIGURE 3 Percentage of ETR in protected and treated leaves of eucalyptus plants with mechanical pruning, and chemical pruning (glufosinate ammonium) in relation to the control (without pruning). Vertical bars represent confidence interval.

The parts eucalyptus plant applied with glufosinate, had defoliation above $80 \%$, with decreased electron transport rate in treated leaves with glufosinate ammonium, denoting the capacity of glufosinate to cause high defoliation in the parts of the plant where the product is applied, not differing significantly from the defoliation with mechanical artificial pruning. The percentage of pruning with glufosinate ammonium application was higher than $90 \%$, i.e., most treated branches had no regrowth capacity and no leaves at $28 \mathrm{DAA}$; this result did not differ significantly from the mechanical pruning (Figure 4A). An application with excellent coverage and deposition of the herbicide in parts of the plant to be defoliated and debranched is essential, since glufosinate ammonium does not have high translocation rates within the plant (Coetzer et al., 200 I; Everman et al., 2009).

Plant height, number of leaves in the branches of the plant shoot, and dry matter mass of leaves and branches were not affected by the application of glufosinate ammonium when compared to the control without artificial pruning, and artificial mechanical pruning (Figure
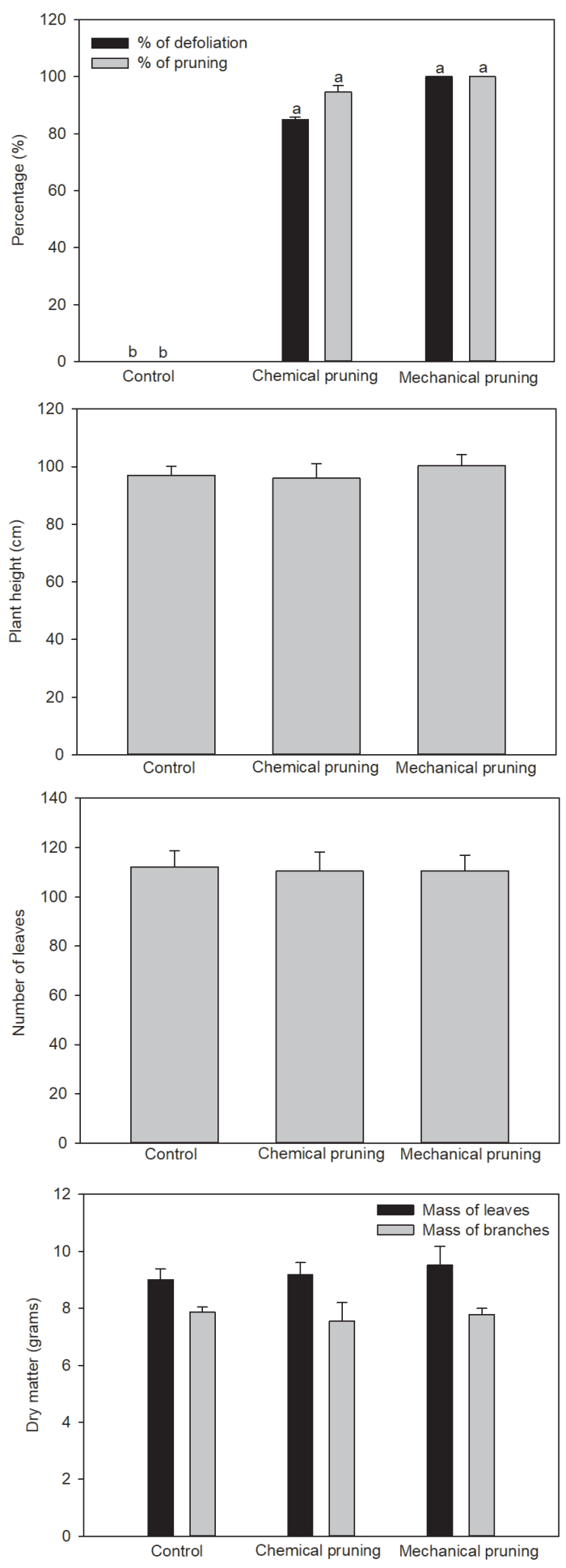

FIGURE 4 Percentage of pruning (A), plant height (B), number of leaves $(C)$, and dry matter mass of leaves and branches (D) of the upper part of eucalyptus plants at 28 days after application of the treatments (control with no pruning, chemical pruning with glufosinate ammonium, and mechanical pruning). A - Equal lowercase letters in the columns, within each evaluation date, do not differ by the t-test (LSD) $(p \leq 0.05) ; B, C$ and $D$ were not significant by the $T$ test $(L S D)(p \leq 0.05)$. Vertical bars represent one confidence interval. 
4). This denotes the ability of the plant to maintain its growth without yield loss, even under stress caused by the herbicide. The leaf growth after pruning is directly related to the efficacy of the used practice because plant growth is not negatively affected by the artificial pruning when the plant has the capacity to reestablish its leaf area (Pires et al., 2002; Pulronik et al., 2005; Machado et al., 20I4). Early artificial mechanical pruning has no effect on the plant height, and stem diameter at the ground level in eucalyptus plants (Cezana et al., 2012; Machado et al., 2014).

The results denoted the possibility of using glufosinate ammonium for defoliation and chemical pruning, since it caused a high percentage of pruning (Figure 4), presented no reduction of electron transport rates (Figure 3), presented no accumulation of ammonia and glutamate (Figures $I$ and 2), and had no effect on the growth of untreated parts of the eucalyptus plants. These results demonstrate that with the high rate of pruning, it is difficult for the branches exposed to the herbicide to regain growth, and consequently there will be no development of new branches or lateral shoots, thus guaranteeing a wood free of knots and of better quality. Further experiments can be carried out to fully understand the use of glufosinate ammonium as a pruning agent for eucalyptus plants.

\section{CONCLUSION}

Due to the low or almost non-translocation of glufosinate ammonium in parts of the eucalyptus plants that were not exposed to the herbicide, it can be used as a possible tool for chemistry artificial pruning, considering that does not affect the physiology and growth of plants eucalyptus.

\section{REFERENCES}

BRITO, I. P. F. S.; MARCHESI, B. B.; PUCCI, C.; CARBONARI, C. A.; VELINI, E. D. Variation in the Sensitivities of Hairy Beggarticks (Bidens pilosa) Plants and Their Progenies to Glufosinate Ammonium. Weed science, v. 64, n. 4, p. 570578, 2016.

BRITO, I. P.F.S.; MORAES, C. P.; MARCHESI, B. B.; CARBONARI, C. A.; VELINI, E.D. Sensitivity of morningglory plants and their progenies to glufosinate ammonium. Planta Daninha, v. 35, 2017 a.

BRITO, I. P.F. S.; MORAES, C. P.; MARCHESI, B. B.; CARBONARI, C. A.; VELINI, E.D. Variation in the sensitivity of wandering jew plants to glufosinate ammonium. Revista Caatinga, v. 30, n. 3, p. 595-60I, 2017 b.
CEZANA, D. P.; CHICHORRO, J. F.; MARTINS, L. T.; COTTA, T. R.; SILVA, J. L. Efeito de diferentes classes de altura e intensidades de desrama artificial sobre o crescimento de um híbrido de eucalipto. Floresta, v. 42, n. I, p. I37-I44, 2012.

COETZER, E.; AL-KHATIB, K.; LOUGHIN, T. M. Glufosinate efficacy, absorption, and translocation in amaranth as affected by relative humidity and temperature. Weed Science, v. 49, n. I, p. 8-13, 200I.

DAYAN F. E.; OWENS D. K.; CORNIANI, N.; SILVA, F. M. L.; WATSON, S. B.; HOWELL, J. L.; SHANER, D. L. Biochemical markers and enzyme assays for herbicide mode of action and resistance studies. Weed Science v. 63, n. spl, p. 23-63, 2015.

DAYAN, F. E.; ZACCARO, M. L. D. M. Chlorophyll fluorescence as a marker for herbicide mechanisms of action. Pesticide Biochemistry and Physiology. v. 102, n. 3, p. 189-197, 2012.

DE FREITAS, I. P.; CARBONARI, C. A.; VELINI, E. D.; SILVA JR, J. F; TROPALDI, L.; GOMES, G. L. G. C. Absorption velocity of glufosinate and its effects on weeds and cotton. Agrociencia, v. 50, n. 2, p. 239-249, 2016.

EVERMAN, W. J.; MAYHEW, C. R.; BURTON, J. D.; YORK, A. C.; WILCUT, J. W. Absorption, translocation, and metabolism of I4C-glufosinate in glufosinate-resistant corn, goosegrass (Eleusine indica), large crabgrass (Digitaria sanguinalis), and sicklepod (Senna obtusifolia). Weed Science, v. 57, n. I, p. I-5, 2009a.

EVERMAN, W. J.; THOMAS, W. E.; BURTON, J. D.; YORK, A. C.; WILCUT, J. W. Absorption, translocation, and metabolism of glufosinate in transgenic and nontransgenic cotton, Palmer amaranth (Amaranthus palmeri), and pitted morningglory (Ipomoea lacunosa). Weed Science, v. 57, n. 4, p. 357-36I, 2009b.

FERRAZ, F; MOLA-YUDEGO, B.; GONZÁLEZ-OLABARRIA, J. R.; SCOLFORO, J. R. S. Pruning effect in Eucalyptus grandis $x$ Eucalyptus urophylla clone growth. Scientia Forestalis, v. 44 , n. III, p. $729-738,2016$ a.

FERRAZ FILHO, A. C.; DE CARVALHO, L. A.; RIBEIRO, A.; GOMIDE, L. R.; SCOLFORO, J. E. R. S. Pruning of Eucalyptus grandis $\mathrm{x}$ Eucalyptus urophylla planted at low density in Southeastern Brazil. African Journal of Agricultural Research, v. II, n. 13, p. II59-। I63, 2016.

FINGER, C. A. G.; SCHEIDER, P. R.; BAZZO, J. L.; KLEIN, J. E. M. K. Efeito da intensidade de desrama sobre o crescimento e a produção de Eucalyptus saligna Smith. CERNE, Lavras, v. 7, n. 2, p. 53-64, 200 I.

HOPPE, J. M.; FREDDO, A. R. Efeito da intensidade de desrama na produção de Pinus elliottii Engelm. no município de Piratini, RS. Ciência Florestal, Santa Maria, v. I3, n. 2, p. 47-56, 2003. 
INSTITUTO BRASILEIRO DE GEOGRAFIA E ESTATÍSTICA. Produção da produção da estação vegetal e da silvicultura (2016). Available at: <https://sidra. ibge.gov.br/tabela/5930\# resultado $>$. Accessed in 23 February 2018.

KLECZKOWSKI, L. A. Inhibitors of photosynthetic enzymes/ carriers and metabolism. Ann. Rev. Plant Physiol. Plant Molecular Biology, v. 45, n. I, p. 339-367, 1993.

LOGUSCH, E. W.; WALKER, D. M.; McDONALD, J. F.; FRANZ, J. E. 1991. Inhibition of plant glutamine synthetases by substituted phosphinothricins. Plant Physiology, v. 95, n. 4, p. 1057-1062.

MACHADO, M. S.; OLIVEIRA NETO, S. N.; FONTES, D. R.; FERREIRA, L. R.; FERREIRA, G. L.; MACHADO, A. F. L. Métodos de controle de plantas daninhas e desrama precoce no crescimento do eucalipto em sistema silvipastoril. Planta Daninha, v. 32, n. I, p. 133-140, 2014.

MASCHHOFF, J. R.; HART, S. E.; BALDWIN, J. L. Effect of ammonium sulfate on the efficacy, absorption, and translocation of glufosinate. Weed Science, v. 48, n. I, p. 2-6, 2000.

PIRES, B. M.; REIS, M. G. F.; REIS, G. G. Crescimento de Eucalyptus grandis submetido a diferentes intensidades de desrama artificial na região de Dionísio, MG. Brasil Florestal, v. 21, n. 73, p. |3-2|, 2002.
POLLI, H. Q.; DOS REIS, G. G.; REIS, M. D. G. F.; VITAL, B. R.; PEZZOPANE, J. E. M.; FONTAN, I. C. I. Qualidade da madeira em clone de Eucalyptus grandis,W. Hill ex Maiden submetido a desrama artificial. Revista Árvore, v. 30, n. 4, p.557-566, 2006.

PORNPROM, T.; CHOMPOO, J.; GRACE, B. Glufosinate tolerance in hybrid corn varieties based on decreasing ammonia accumulation. Weed biology and Management, v. 3, n. I, p. 4I-45, 2003.

PULROLNIK, K.; REIS, G.G.; REIS, M. G. F.; MONTE, M. A.; FONTAN, I. C. I. Crescimento de plantas de clone de Eucalyptus grandis [hill ex maiden] submetidas a diferentes tratamentos de desrama artificial, na região de cerrado. Revista Árvore, v. 29, n. 4, p. 495-505, 2005.

TAN, S.; EVANS, R.; SINGH, B. Herbicidal inhibitors of amino acid biosynthesis and herbicide-tolerant crops. Amino Acids, v. 30, n. 2, p. 195-204, 2006.

TSAI, C. J.; WANG, C. S.; WANG, C. Y. Physiological characteristics of glufosinate resistance in rice. Weed science, v. 54, n. 4, p. 634-640, 2006.

VALE, R. S.; MACEDO, R. L. G.; VENTURIN, N.; MORI, F. A.; MORAIS, A. R. Efeito da desrama artificial na qualidade da madeira de clones de eucalipto em sistema agrossilvipastoril. Revista Árvore, v. 26, n. 3, p. 285-297, 2002.

WENDLER, C.; BARNISKE, M.; WILD, A. Effect of phosphinothricin (glufosinate) on photosynthesis and photorespiration of C3 and C4 plants. Photosynthesis Research, v. 24, n. I, p. 55-6I, 1990. 